\title{
Overview of Different Waste Treatment Methods
}

\author{
Nida Tabassum Khan ${ }^{1}$, Namra Jameel ${ }^{2}$, Maham Jamil Khan ${ }^{3}$ \\ ${ }^{1}$ Department of Biotechnology, Faculty of Life Sciences and Informatics, Balochistan University of Information Technology \\ Engineering and Management Sciences,(BUITEMS),Quetta, Pakistan. \\ ${ }^{2}$ OGDCL (Oil and Gas Development Company Limited)-Islamabad-Pakistan. \\ ${ }^{3}$ Sukkur IBA University-Undergraduate student-Sukkur-Pakistan
}

\begin{abstract}
Wastes including chlorinated aliphatic hydrocarbons, refractory organic compounds, aromatic derivatives, radionuclides etc., poses a serious threat to the environment. Therefore numerous in situ /ex situ treatment method are formulated to remove or immobilize such contaminates occurring in soil, water or air to minimize its harmful effects.

Key words: Front end nuclear fuel cycle; Nuclear medicine; Compaction; Sanitary landfills; Soil vapor extraction.
\end{abstract}

\section{INTRODUCTION}

Radioactive waste is waste with the potential to emit radioactive radiations and is termed as radioactive waste (Lutzeet al.,1988). It is usually a by-product of nuclear reactions such as fission or fusion technology occurring in a nuclear reactor (Ewinget al.,1995). There are numerous sources of radioactive waste such as from nuclear power plants, nuclear deployment or nuclear fuel treatment plants, nuclear weapons reprocessing, biomedical and industrial wastes, radionuclides accumulation etc (Chapman et al.,1987).

\section{Sources of Nuclear Waste}

- Front end nuclear fuel cycle: It is usually uranium containing waste emitting alpha particles. It often contains radium and its decay products as well (Schneider et al., 2013).

- Back end nuclear fuel cycle: Waste containing fission products which emits beta/ gamma particles, and actinides that discharge alpha particles such as uranium-234, americium-241, neptunium-237, californium, plutonium-238 and 239 etc (Madic et al.,2007; Ewing et al.,2011)

- Nuclear weapons decommissioning: Waste produced from nuclear weapons neutralizing contains beta/ gamma particles, alpha-emitting actinides such as Pu-239 and Pu-238 or Po (Jo et al., 2007).

- Legacy waste: It includes abandoned waste from radium industry, uranium mining, and military programs (National Research Council, 2000).

- Nuclear medicine: Medical waste includes sources of beta and gamma ray emitters such as Y-90, Cs-137, Ir-192, I-131, Sr-89, Co-60 etc., (Cherry et al., 2012; Ravichandran et al., 2011)

- Industry: Industrial waste contain S alpha, beta, neutron or gamma emitters (Ojovan et al., 2011)

- Naturally occurring radio nuclides: Uranium and thorium radioisotopes from coal combustion, residues from oil and gas industry often contain radium and its decay products (Walsh et al., 2010).

\section{Treatment of Nuclear Waste}

\section{Treatmentof nuclear waste}

Radioactive waste is converted into a more stable forms that is neutral for the environment

The major objectives are as follows:

- Reduction of nuclear waste volume

- Minimizing the hazardous potential of nuclear waste by immobilization with inert matrix and containment.

- Strict regulation of nuclear waste management policy

- Storage of immobilized nuclear waste in impenetrable containers/canisters (Nash et al., 2011;Rajet al.,2006;Efremenkov et al., 1989).

\section{Corresponding author \\ Dr. Nida Tabassum Khan \\ Email: nidatabassumkhan@yahoo.com}

Received: 28-05-2018 


\section{Nuclear Waste Treatment Methods}

- Incineration: Combustible radioactive waste is incinerated in engineered kiln to reduce volume (Tzenget al., 1998). After incineration, the resulting radionuclide residues require further cementation preceding to disposal (Heberlein et al., 2008).

- Compaction: Another technique is to reduce radioactive waste volume in compactors in order to be transported to a waste treatment facility for further compaction or to a storage/disposal facility (Burstrom et al., 1987)

- Cementation: Away to immobilize radioactive waste into sludge, gels or fragmented solids (Osmanlioglu et al., 2002).

- Encapsulation: A way to encapsulate non reprocessed fuel for long term storage (Suthanthiran et al.,1990)

\section{Treatment of GroundWater Contaminants}

Groundwater remediation involves the treatment of pollutants by transforming them into harmless forms in order tominimize the undesirable effects of contaminants (Lapworth et al., 2012)

\section{Ground Water Treatment Methods}

- Pump treatment method: Extraction of contaminated groundwater from the subsurface to the pumping wells for treatment later the treated clean water is returned to the subsurface. Though it's a slow treatment process (Mackay et al.,1989)

- Soil vapor extraction: It involves the passage of large volumes of air through a polluted spill which causes evaporation of volatile pollutants into the air which are then transported to the surface (Mulligan et al., 2001)

- Bioremediation: It involves the use of microbes for the biodegradation of pollutants present in the groundwater by stimulating the surrounding conditions through the addition of nutrients and oxygen to increase microbial degrading activity (Chapelle,1999)

- Ion exchange: Downward passage of water under pressure through a fixed bed of granular medium or spherical beads often made of zeolites and synthetic resins (Gupta et al.,2012)

- Biosparging: It uses native microbes to degrade organic contaminants present in the groundwater by stimulating the surrounding conditions through the addition of nutrients and oxygen to increase the biological activity of the microorganisms (Wilson et al.,1996).

\section{Treatment of Soil Contaminants}

Landfill technologies are intended to promote anaerobic biodegradation of organic waste (Evangelou et al., 1998).

\section{Soil Contamination Treatment Methods}

- Sanitary landfills: It uses a clay liner to separate the waste from the environment and then deposited into thin layers for compaction in order to prevent the escape of potentially dangerous constituents (Chian et al.,1976).

There are three main types of this method

1. Area method: It involves the spreading and compaction of wastes then encapsulation with an inert material (Siddiqui et al.,1996).

2. Trench method: It involves the excavation of trench into which the solid wastes are spread, compressed and concealed (Reinhart et al.,1997). The top of the finished landfill is raised above the original ground level (Pohland et al.,1973).

3. Slope method: The wastes are spread on an existing slope, compacted and covered (Singh et al.,1990).

- Construction and demolition waste landfills: Landfill use to manage the waste generated from construction, renovation, and demolition of buildings, roads, and bridges (Waste,1995).

- Coal combustion residual landfills: Waste landfill to manage and dispose of coal combustion residuals (Wadge et al.,1987).

\section{Challenges of Landfill Waste Management}

1. Groundwater contamination

2. Leachate production

3. Static load failures

4. Constantly rebuilding failing slopes (Zhang et al., 2010; Guerrero et al., 2013)

\section{CONCLUSION}

Thus the main aim of these contaminant treatment methods is to provide a safe and economical means of removing hazardous organic/inorganic waste from the environment either by completely degrading the contaminants in situ or ex situ in order to reduce the cost of treatment method.

\section{REFERENCES}

1. Burstrom M \& Tegman R (1987). U.S. Patent No. 4,642,204. Washington, DC: U.S. Patent and Trademark Office. 
2. Chapelle FH (1999). Bioremediation of petroleum hydrocarbon-contaminated ground water: The perspectives of history and hydrology. Groundwater. 37(1):122-132.

3. Chapman NA \& Mc Kinley IG (1987). The geological disposal of nuclear waste

4. Cherry SR, Sorenson JA \& Phelps ME (2012). Physics in nuclear medicine e-Book. Elsevier Health Sciences.

5. Chian ES \& Dewalle FB (1976). Sanitary landfill leachates and their leachate treatment. Journal of the Environmental Engineering Division, 102(2):411-431.

6. Efremenkov VM (1989). Radioactive waste management at nuclear power plants. IAEA Bulletin. 31(4):37-42.

7. Evangelou VP \& Evangelou VP (1998). Environmental soil and water chemistry: principles and applications.

8. Ewing RC (2011). Actinides and radiation effects: impact on the back-end of the nuclear fuel cycle. Mineralogical Magazine. 75(4):2359-2377.

9. Ewing RC Weber WJ \& Clinard Jr, FW (1995). Radiation effects in nuclear waste forms for high-level radioactive waste. Progress in nuclear energy. 29(2):63-127.

10. Guerrero LA, Maas G \& Hogland W (2013). Solid waste management challenges for cities in developing countries. Waste management. 33(1):220-232.

11. Gupta VK, Ali I, Saleh TA, Nayak A \& Agarwal S (2012). Chemical treatment technologies for waste-water recyclingan overview. Rsc Advances. 2(16):6380-6388.

12. Heberlein J \& Murphy AB (2008). Thermal plasma waste treatment. Journal of Physics D: Applied Physics. 41(5): 053001.

13. Jo DJ \& Gartzke E (2007). Determinants of nuclear weapons proliferation. Journal of Conflict Resolution. 51(1):167-194.

14. Lapworth DJ, Baran N, Stuart ME \& Ward RS (2012). Emerging organic contaminants in groundwater: a review of sources, fate and occurrence. Environmental pollution. 163:287-303.

15. Lutze W \& Ewing RC (1988). Radioactive waste forms for the future.

16. Mackay DM \& Cherry JA (1989). Groundwater contamination: pump-and-treat remediation. Environmental Science $\mathcal{E}$ Technology. 23(6):630-636.

17. Madic C, Boullis B, Baron P, Testard F, Hudson MJ, Liljenzin JO \& Modolo G (2007). Futuristic back-end of the nuclear fuel cycle with the partitioning of minor actinides. Journal of Alloys and Compounds. 444:23-27.

18. Mulligan CN, Yong RN \& Gibbs BF (2001). Remediation technologies for metal-contaminated soils and groundwater: an evaluation. Engineering geology. 60(1-4):193-207.

19. Nash KL \& Lumetta GJ (Eds.) (2011). Advanced separation techniques for nuclear fuel reprocessing and radioactive waste treatment. Elsevier.

20. National Research Council. (2000). Long-term institutional management of US Department of Energy legacy waste sites. National Academies Press.
21. Ojovan MI \& Lee WE (2013). An introduction to nuclear waste immobilisation. Newnes.

22. Osmanlioglu AE (2002). Immobilization of radioactive waste by cementation with purified kaolin clay. Waste Management. 22(5):481-483.

23. Pohland FG (1973). Sanitary landfill stabilization with leachate recycle and residual treatment. Georgia Institute of Technology.

24. Raj K, Prasad KK \& Bansal NK (2006). Radioactive waste management practices in India. Nuclear Engineering and Design. 236(7-8):914-930.

25. Ravichandran R, Binukumar JP, Sreeram R \& Arunkumar LS (2011). An overview of radioactive waste disposal procedures of a nuclear medicine department. Journal of Medical Physics/ Association of Medical Physicists of India. 36(2):95.

26. Reinhart DR \& Townsend TG (1997). Landfill bioreactor design \& operation. CRC press.

27. Schneider E, Carlsen B, Tavrides E, Van Der Hoeven C \& Phathanapirom U (2013). Measures of the environmental footprint of the front end of the nuclear fuel cycle. Energy Economics. 40:898-910.

28. Siddiqui MZ, Everett JW \& Vieux BE (1996). Landfill siting using geographic information systems: a demonstration. Journal of environmental engineering. 122(6):515-523.

29. Singh S \& Murphy BJ (1990). Evaluation of the stability of sanitary landfills. In Geotechnics of Waste Fills-Theory and Practice. ASTM International.

30. Suthanthiran K (1990). U.S. Patent No. 4,891,165. Washington, DC: U.S. Patent and Trademark Office.

31. Tzeng CC, Kuo YY, Huang TF, Lin DL \& Yu YJ (1998). Treatment of radioactive wastes by plasma incineration and vitrification for final disposal. Journal of Hazardous Materials. 58(1-3):207-220.

32. Wadge A \& Hutton M (1987). The leachability and chemical speciation of selected trace elements in fly ash from coal combustion and refuse incineration. Environmental Pollution. 48(2):85-99.

33. Walsh M (2010). Naturally occurring radionuclides.

34. WASTE D (1995). Construction and Demolition Waste Landfills.

35. Wilson DJ, Norris RD \& Clarke AN (1996). Groundwater cleanup by in-situ sparging. $X$. Air channeling model for biosparging of nonaqueous phase liquid. Separation science and technology. 31(10):1357-1376.

36. Zhang DQ, Tan SK \& Gersberg RM (2010). Municipal solid waste management in China: status, problems and challenges. Journal of environmental management. 91(8):1623-1633.

How to cite article: Nida Tabassum Khan, Namra Jameel, Maham Jamil Khan (2018). Overview of different waste treatment methods. Int. J. Appl. Pharm. Sci. Res. 3(3):33-35. doi: https://doi.org/10.21477/ijapsr.3.3.2

Source of Support; Nil Conflict of Interest: None declared 